\title{
Studi Perbaikan Stabilitas Tegangan Sistem Jawa-Madura- Bali (Jamali) dengan Pemasangan SVC Setelah Masuknya Pembangkit 1000 MW Paiton
}

\author{
Heru Pujo Prayitno, Ontoseno Penangsang, Ni Ketut Aryani \\ Jurusan Teknik Elektro, Fakultas Teknologi Industri, Institut Teknologi Sepuluh Nopember (ITS) \\ Jl. Arief Rahman Hakim, Surabaya 60111, Indonesia \\ e-mail: ketut.aryani@gmail.com, ontosenop@ee.its.ac.id, herupujo80@gmail.com.
}

\begin{abstract}
Abstrak - Sebagian besar pemadaman sistem tenaga listrik yang terjadi disebabkan oleh tekanan yang tinggi pada sistem daya dengan besarnya permintaan daya aktif dan reaktif dan kondisi tegangan yang rendah. Ketika tegangan pada sistem tenaga bus rendah, kerugian juga akan meningkat. Sehingga diperlukan pengembangan teknik khusus untuk meningkatkan tegangan dan menghilangkan ketidakstabilan tegangan dalam sistem tenaga. Flexible Alternating Current Transmission Systems (FACTS ) sangat intensif untuk menjaga stabilitas tegangan pada jalur transmisi untuk memanipulasi aliran daya. Performa sistem tenaga dan stabilitas sistem tenaga dapat ditingkatkan dengan menggunakan perangkat FACTS, salah satunya dengan Static VAR Compensator (S VC). Pada tugas akhir ini bertujuan untuk memperbaiki stabilitas tegangan terutama memperbaiki profil tegangan terhadap penambahan suatu beban $P$ dan $Q$ pada rencana pengembangan sistem kelistrikan Jawa-Madura-Bali (Jamali) $500 \mathrm{kV}$ tahun 2021 dengan pemasangan S VC pada bus yang sensitif. Analisis stabilitas tegangan dapat dilakukan dengan metode kestabilan kurva PV. Hasil perbandingan kurva PV sebelum dan sesudah pemasang $\mathrm{S} V \mathrm{C}$ dapat menunjukkan adanya perbaikan perbedaan kestabilan tegangan. Perbaikan tegangan dengan menggunakan S VC dapat menjaga tegangan untuk tetap berada pada batas nilai kestabilan tegangan.
\end{abstract}

Kata kunci : Kestabilan tegangan, Static VAR Compensator (S VC), Kurva PV, Sistem Kelistrikan Jamali 500kV-2021.

\section{PENDAHULUAN}

$\mathrm{S}$ ISTEM tenaga listrik harus bekerja secara optimal dalam melayani beban yang bersifat fluktuatif dan jenis beban yang beragam. Kharakteristik beban sangat mempengaruhi kapasitas (capacity) dan kemampuan (capability) sistem dalam menyalurkan daya. Konfigurasi jaringan yang luas dan berkembang juga menyebabkan pengoperasian sistem tenaga listrik menjadi lebih rumit dan sulit dikontrol. Salah satu masalah yang timbul adalah terjadinya gangguan yang mengakibatkan ketidakstabilan tegangan pada sistem.

Sebagian besar pemadaman sistem tenaga listrik yang terjadi disebabkan oleh tekanan yang tinggi pada sistem daya dengan besarnya permintaan daya aktif dan reaktif dan kondisi tegangan yang rendah. Ketika tegangan pada sistem tenaga bus rendah, kerugian juga akan meningkat. Sehingga diperlukan pengembangan teknik khusus untuk meningkatkan tegangan dan menghilangkan ketidakstabilan tegangan dalam sistem tenaga. Flexible Alternating Current Transmission Systems
(FACTS) sangat intensif untuk menjaga stabilitas tegangan pada jalur transmisi untuk memanipulasi aliran daya. FACTS bekerja secara fleksibel dan secara langsung dapat digunakan untuk transfer daya reaktif yang sangat membantu dalam pengoperasian jaringan listrik. Performa sistem tenaga dan stabilitas sistem tenaga dapat ditingkatkan dengan menggunakan perangkat FACTS [1], salah satunya dengan Static VAR Compensator (SVC) [2].

Peralatan FACTS merupakan peralatan elektronika daya yang dapat mengubah parameter seperti impedansi, tegangan dan sudut fasa. FACTS juga membantu untuk mengurangi arus berlebih pada jaringan, mengakibatkan peningkatan kemampuan beban, menguragi kerugian sistem, meningkatan stabilitas, dan mengurangi biaya produksi dengan mengatur aliran daya paja jaring transmisi. Sehingga dapat mengontrol dengan baik stabilitas aliran daya statis dan aliran daya dinamis [3]. Static Var Kompensator (SVC) adalah salah satu perangkat yang paling efektif untuk meningkatkan stabilitas tegangan dan meningkatkan kemampuan transfer daya jaring transmisi, untuk ini SVC harus terpasang dengan benar pada sistem dengan parameter yang sesuai. Beberapa faktor dipertimbangkan untuk pengoptimalan instalasi dan pengoptimalan parameter SVC, dengan tujuan meningkatkan margin stabilitas tegangan sehingga diperoleh peningkatan kapasitas transmisi listrik [4].

Tujuan dari penelitian ini adalah dengan menggunakan analisis dari kurva PV didapatkan batas steady state serta karakteristik dari sebuah sistem, sehingga dapat mengetahui bus yang sensitif terhadap penambahan beban. Dari bus tersebut dipasangkan SVC yang nantinya akan memperbaiki profil tegangan yang terjadi.

\section{TEORI PENUNJANG}

\section{A. Studi Aliran Daya}

Sasaran utarna dari semua analisa aliran daya adalah menentukan besar dan sudut fasa tegangan pada setiap bus, dengan diketahuinya tegangan maka daya aktif $(\mathrm{P})$ dan daya reaktif $(\mathrm{Q})$ dapat dihitung. Jika $\mathrm{P}$ dan $\mathrm{Q}$ pada dua buah bus diketahui maka aliran daya dengan jelas dapat diketahui, serta rugi-rugi daya saluran penghubung dapat diketahui. Pada tiaptiap bus terdiri dari 4 besaran, yaitu: daya aktif $\mathrm{P}$, daya reaktif $\mathrm{Q}$, harga skalar tegangan $|\mathrm{V}|$, dan sudut fasa tegangan $\theta$. 
Ada 3 macam bus dalam hal ini setiap bus mempunyai empat besaran dengan dua besaran diantaranya diketahui yakni:

a. Bus referensi (slack bus). Adalah bus yang selalu mempunyai besaran skalar $(|\mathrm{V}|)$ dan sudut fasa $(\theta)$ yang tetap dan telah diberikan sebelumnya.

b. Bus beban (bus PQ), daya aktif (P) dan daya reaktif (Q) diketahui.

c. Bus generator (bus PV), besar tegangan (|V|) dan daya aktif (P) telah ditentukan.

\section{B. Metode Newton Raphson}

Persamaan umum dari arus yang menuju bus adalah:

$$
I_{i}=\sum_{j=1}^{n} y_{i j} V_{j}
$$

Secara umum, persamaan load flow dapat ditulis sebagai berikut:

$$
P_{i}-j Q_{i}=V_{i}^{*} \sum_{j=1}^{n} V_{j} Y_{i j}
$$

Dalam perhitungan daya aktif (P) dan daya reaktif (Q) dapat diturunkan dari persamaan:

$$
P=V I \cos \theta, \text { dimana } I=V . Y
$$

dengan mestubtitusi persamaan maka didapatkan:

$$
P=V_{1} V_{2} Y \cos \left(\delta_{1}-\delta_{2}-\theta\right)
$$

Jika persamaan tersebut diaplikasikan pada analisa banyak mesin/ multimesin, maka persamaan yang didapat:

$$
P_{i}=V_{i}^{2} G_{i i}+\sum_{i, i \neq j}^{n} \sum_{j}^{n} Y_{i j} V_{i} V_{j} \cos \left(\theta_{i j}+\delta_{i}-\delta_{j}\right)
$$

Pada persamaan $Q$ juga dapat diturunkan dari persaman:

$$
Q=V I \sin \theta
$$

sehingga,

$Q=V_{1} V_{2} Y \sin \left(\delta_{1}-\delta_{2}-\theta\right)$

Jika pada banyak mesin/ multimesin, maka persamaan yang didapat:

$$
Q_{i}=V_{i}^{2} B_{i i}-\sum_{i, i \neq j}^{n} \sum_{j}^{n} Y_{i j} V_{i} V_{j} \sin \left(\theta_{i j}+\delta_{i}-\delta_{j}\right)
$$

Kemudian, setelah daya dan tegangan tiap bus diketahui, maka akan ditentukan matrik Jacobian untuk iterasi selanjutnya. Matrik Jacobian sendiri terdiri dari komponen $H$, komponen $N$, komponen $J$, dan komponen $J$.

$$
\text { Jacobian matrik }=\left[\begin{array}{cc}
H & N \\
J & L
\end{array}\right]
$$

Sehingga, untuk mencari aliran daya setiap bus dapat ditulis persamaan dari load sebagai berikut:

$$
\left[\begin{array}{cc}
H & N \\
J & L
\end{array}\right]\left[\begin{array}{c}
\Delta \theta \\
\frac{\Delta|V|}{|V|}
\end{array}\right]=\left[\begin{array}{c}
\Delta P \\
\Delta Q
\end{array}\right]
$$

Selanjutnya dari perkalian matrik Jacobian diatas, akan didapat nilai dari $\Delta \theta_{i}$ dan $\Delta\left|V_{i}\right|$ yang digunakan sebagai update sudut dan magnitude tegangan tiap bus.

$$
\begin{aligned}
& \theta_{i}^{(k+1)}=\theta_{i}^{(k)}+\Delta \theta_{i} \\
& \left|V_{i}\right|^{(k+1)}=\left|V_{i}\right|^{(k)}+\Delta\left|V_{i}\right|
\end{aligned}
$$

\section{Static VAR Compensator (SVC)}

Static Var Compensator (SVC) adalah komponen FACTS dengan hubungan paralel, yang fungsi utamanya untuk mengatur tegangan pada bus tertentu dengan cara mengontrol besaran reaktansi ekuivalen. Dari sudut pandang operasional, SVC bekerja seperti reaktans variabel shunt, yang bisa menghasilkan atau menyerap daya reaktif untuk mengatur besarnya tegangan pada titik sambungan ke jaringan AC. Kontrol sudut penyalaan thyristor memiliki kecepatan respon yang hampir seketika. SVC digunakan secara luas untuk menyalurkan daya reaktif dan menyediakan support regulasi tegangan dengan cepat. Selain itu SVC juga dipakai untuk meningkatkan batas stabilitas sistem dan mengurangi osilasi daya. Secara umum ada dua konfigurasi SVC, yaitu:

a). Model firing angle SVC (Gambar 1(a))

Pemodelan SVC berupa reaktansi ekuivalen $\mathrm{X}_{\mathrm{SVC}}$, yang merupakan dari perubahan sudut penyalaan $\alpha$, terdiri dari kombinasi paralel admitansi ekuivalen thyristor-controlled reactor (TCR) dan reaktansi kapasitif tetap.

b). Model total susceptance SVC

SVC dilihat sebagai sebuah reaktansi yang dapat diatur melalui perubahan susceptansi $B_{S V C}$, yang melambangkan nilai susceptansi SVC total yang diperlukan untuk mempertahankan besar tegangan bus pada nilai tertentu, seperti ditunjukkan pada Gambar 1(b).

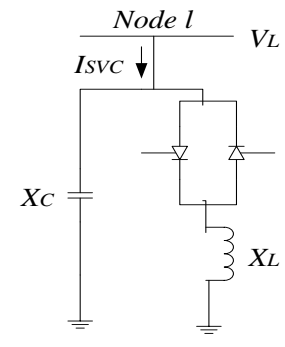

(a)

Gambar 1. Konfigurasi SVC

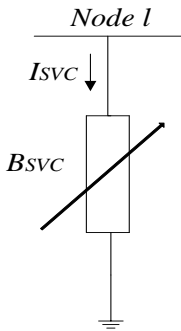

(b)
Dengan mengacu pada gambar 1(b), arus yang dialirkan oleh SVC adalah

$I_{S V C}=j B_{S V C} V_{l}$

dan daya reaktif yang dibangkitkan oleh SVC, yang juga merupakan daya reaktif yang diinjeksikan pada bus 1, adalah

$Q_{S V C}=Q_{l}=-V_{l}^{2} B_{S V C}$

\section{Sensitivitas Tegangan}

Sensitivitas tegangan adalah keadaan dimana tegangan pada bus jika dilakukan penambahan beban, atau dengan keadaan normal dilakukan aliran daya, keadaan beban pada bus beban tidak mengalami penurunan. Penurunan tegangan pada bus beban diakibatkan dengan adanya suatu penambahan beban secara kontinyu. Jika penambahan beban pada bus dan sumber listrik tidak dilakukan penambahan sumber, maka drop tegangan akan terjadi pada bus tersebut.

Metode Newton Raphson digunakan untuk menganalisa sensitifitas tegangan pada masing-masing bus pada jaringan. Adapun untuk mengetahui besar selisih tegangan $(\Delta \mathrm{V})$ pada masing-masing bus sehingga dapat dilihat perubahan tegangan pada bus. Persamaan drop tegangan pada bus adalah:

$$
\Delta\left|V_{i}\right|=\left|V_{i}^{k}\right|-\left|V_{i}\right|^{(k+1)}
$$




\section{PEMODELAN SISTEM}

\section{A. Sistem Kelistrikan Jamali $500 \mathrm{kV}$}

Data parameter yang digunakan meliputi data saluran (line), data pembangkit (generation), dan data beban (load) pada aliran daya $500 \mathrm{kV}$ tahun 2021 pada saat beban puncak (peak load) pukul 19.00 WIB. Dimana jumlah total beban yang terpasang adalah $38.900 \mathrm{MW}$ dan 18.840,4 MVAR.

Bus yang digunakan dapat diklasifikasikan sebagai berikut:

1. Slack bus (1 bus) yaitu bus Suralaya yang merupakan pembangkit listrik tenaga uap, magnitude tegangan dan sudut phase ditetapkan.

2. Generator bus (19 bus) yaitu Cirata, Saguling, Matenggeng, Banten, Bojanegara, Balaraja, Tanjung Pucut, Rawalo, Cirebon, Jawa Tengah, Indramayu, Tanjung Jati, Muara Karang, Priok, Muara Tawar, Jawa1, Grati, Gresik, dan Paiton.

3. Load bus (30 bus) yaitu bus Cilegon, Lengkong, Gandul, Kembangan, Durikosambi, Bekasi, Cawang, Bogor, Depok, Cibinong, Tambun, Cikalong, Tasik, Pedan, Kediri, Bangil, Cibatu Baru, Cibatu, Deltamas, Bandung Selatan, Ujung Berung, Mandirancan, Pemalang, Ungaran, Ampel, Ngimbang, Krian, Surabaya Selatan, Tandes, dan Kapal.

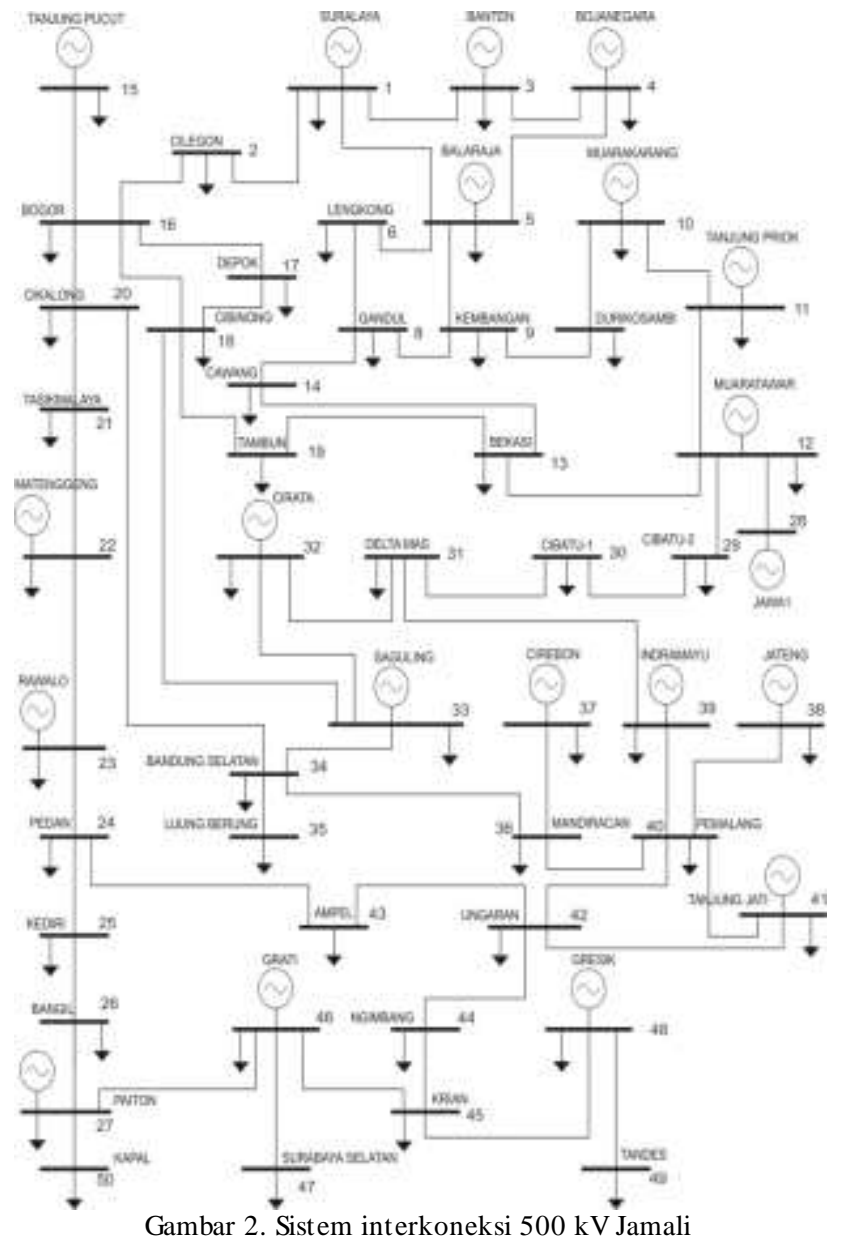

Data saluran dan data bus yang digunakan untuk proses simulasi ditunjukkan tabel 1. Dimana impedansi base $\left(Z_{\mathrm{B}}=\right.$ $2500 \Omega)$ dan admitansi base $\left(\mathrm{Y}_{\mathrm{B}}=0,0004 \widetilde{\sigma}\right)$.

Tabel 1.

Data saluran sistem interkoneksi $500 \mathrm{kV}$ Jamali

\begin{tabular}{|c|c|c|c|c|c|}
\hline No. & Dari Bus & "Ke Bus & $\overline{\mathrm{R}(\mathrm{pu})}$ & $\overline{\mathrm{X}(\mathrm{pu})}$ & $\overline{\mathrm{B}(\mathrm{pu})}$ \\
\hline 1 & 1 & 2 & 0,00007 & 0,00072 & 0,26116 \\
\hline 2 & 1 & 5 & 0,00038 & 0,00362 & 1,2968 \\
\hline 3 & 3 & 4 & 0,00006 & 0,00056 & 0,2016 \\
\hline 4 & 3 & 1 & 0,00006 & 0,00056 & 0,2016 \\
\hline 5 & 4 & 5 & 0,00035 & 0,00338 & 1,21001 \\
\hline 6 & 5 & 8 & 0,0004 & 0,00449 & 1,62058 \\
\hline 7 & 6 & 5 & 0,00018 & 0,00175 & 0,62502 \\
\hline 8 & 6 & 7 & 0,00008 & 0,00084 & 0,30368 \\
\hline 9 & 7 & 14 & 0,0002 & 0,00225 & 0,80992 \\
\hline 10 & 7 & 17 & 0,00004 & 0,00042 & 0,15184 \\
\hline 11 & 7 & 8 & 0,00015 & 0,00169 & 0,60943 \\
\hline 12 & 9 & 8 & 0,00003 & 0,00034 & 0,12147 \\
\hline 13 & 10 & 11 & 0,0001 & 0,00112 & 0,40492 \\
\hline 14 & 10 & 9 & 0,00015 & 0,00169 & 0,6074 \\
\hline 15 & 11 & 12 & 0,00015 & 0,00169 & 0,6074 \\
\hline 16 & 13 & 19 & 0,0001 & 0,00101 & 0,36088 \\
\hline 17 & 13 & 12 & 0,0001 & 0,00118 & 0,42516 \\
\hline 18 & 14 & 13 & 0,00012 & 0,00113 & 0,40321 \\
\hline 19 & 15 & 16 & 0,00108 & 0,01224 & 4,47444 \\
\hline 20 & 16 & 17 & 0,00003 & 0,00034 & 0,12147 \\
\hline 21 & 16 & 20 & 0,00077 & 0,00861 & 3,12475 \\
\hline 22 & 16 & 2 & 0,00035 & 0,00397 & 1,43403 \\
\hline 23 & 17 & 18 & 0,00008 & 0,00079 & 0,28225 \\
\hline 24 & 18 & 33 & 0,00041 & 0,00459 & 1,65912 \\
\hline 25 & 18 & 19 & 0,00012 & 0,00113 & 0,40321 \\
\hline 26 & 18 & 16 & 0,0003 & 0,00337 & 1,21511 \\
\hline 27 & 20 & 34 & 0,00004 & 0,00045 & 0,16196 \\
\hline 28 & 20 & 21 & 0,0006 & 0,00672 & 2,43272 \\
\hline 29 & 21 & 22 & 0,0001 & 0,00112 & 0,4049 \\
\hline 30 & 22 & 23 & 0,0004 & 0,00449 & 1,62058 \\
\hline 31 & 23 & 24 & 0,00101 & 0,01137 & 4,14634 \\
\hline 32 & 24 & 43 & 0,00009 & 0,00086 & 0,30845 \\
\hline 33 & 24 & 25 & 0,001 & 0,01128 & 4,11357 \\
\hline 34 & 25 & 26 & 0,00054 & 0,00606 & 2,19091 \\
\hline 35 & 26 & 27 & 0,00051 & 0,00566 & 2,04672 \\
\hline 36 & 28 & 12 & 0,0001 & 0,00112 & 0,40492 \\
\hline 37 & 29 & 30 & 0,0001 & 0,00112 & 0,40492 \\
\hline 38 & 29 & 12 & 0,00017 & 0,00159 & 0,56855 \\
\hline 39 & 31 & 32 & 0,00022 & 0,00214 & 0,76618 \\
\hline 40 & 31 & 30 & 0,00004 & 0,00045 & 0,16196 \\
\hline 41 & 33 & 34 & 0,00019 & 0,00211 & 0,76131 \\
\hline 42 & 33 & 32 & 0,00015 & 0,00142 & 0,50806 \\
\hline 43 & 34 & 36 & 0,0007 & 0,0067 & 2,41036 \\
\hline 44 & 34 & 35 & 0,00029 & 0,00281 & 1,00824 \\
\hline 45 & 35 & 36 & 0,0004 & 0,00383 & 1,37148 \\
\hline 46 & 36 & 40 & 0,00079 & 0,00894 & 3,24708 \\
\hline 47 & 37 & 36 & 0,00023 & 0,00225 & 0,80652 \\
\hline 48 & 38 & 40 & 0,0002 & 0,00225 & 0,80992 \\
\hline
\end{tabular}




\begin{tabular}{cccccc}
\hline \hline 49 & 39 & 40 & 0,00146 & 0,01424 & 5,19319 \\
50 & 39 & 31 & 0,00052 & 0,00577 & 2,08733 \\
51 & 40 & 42 & 0,00032 & 0,00353 & 1,27592 \\
52 & 41 & 42 & 0,00067 & 0,00754 & 2,73374 \\
53 & 41 & 40 & 0,00127 & 0,01442 & 5,29767 \\
54 & 42 & 44 & 0,0012 & 0,0116 & 4,2044 \\
55 & 43 & 42 & 0,0003 & 0,00337 & 1,21511 \\
56 & 45 & 48 & 0,00012 & 0,00129 & 0,46566 \\
57 & 45 & 46 & 0,00046 & 0,00518 & 1,87215 \\
58 & 45 & 44 & 0,00028 & 0,00268 & 0,95982 \\
59 & 46 & 47 & 0,00079 & 0,00894 & 3,24708 \\
60 & 46 & 27 & 0,00044 & 0,00493 & 1,78084 \\
61 & 48 & 49 & 0,00008 & 0,00073 & 0,26208 \\
62 & 50 & 27 & 0,00218 & 0,02556 & 9,82732 \\
\hline \hline
\end{tabular}

Data pembangkitan dan data bus ditunjukkan pada tabel 2. Dimana $\left(\mathrm{MVA}_{\mathrm{B}}=100 \mathrm{MVA}\right)$ dan $\left(\mathrm{V}_{\mathrm{B}}=500 \mathrm{kV}\right)$.

$$
\text { Tabel } 2 .
$$

Data pembangkitan sistem interkoneksi $500 \mathrm{kV}$ Jamali

\begin{tabular}{ccccccccc}
\hline \hline \multirow{2}{*}{ No } & Bus & \multicolumn{2}{c}{ Load } & \multicolumn{2}{c}{ Generator } & Qmax & Qmin & Qinj \\
\cline { 2 - 8 } Bus & Code & MW & MVAR & MW & MVARMVAR MVAR MVAR \\
\hline 1 & 1 & 219 & 106,1 & 2071,9 & 1494,8 & 2189,1 & $-964,07$ & 0 \\
2 & 0 & 475,3 & 230,2 & 0 & 0 & 0 & 0 & 0 \\
3 & 2 & 0 & 0 & 1552,5 & $-176,9$ & 1069,1 & $-334,2$ & 0 \\
4 & 2 & 0 & 0 & 1600 & 383,25 & 1239,5 & $-387,6$ & 0 \\
5 & 2 & 2185,2 & 1058,3 & 1197 & 1239,5 & 1239,5 & $-387,5$ & 0 \\
6 & 0 & 900 & 435,9 & 0 & 0 & 0 & 0 & 0 \\
7 & 0 & 814 & 394,2 & 0 & 0 & 0 & 0 & 0 \\
8 & 0 & 551 & 266,9 & 0 & 0 & 0 & 0 & 0 \\
9 & 0 & 1950,3 & 944,6 & 0 & 0 & 0 & 0 & 0 \\
10 & 2 & 900 & 435,9 & 1398 & 609,4 & 609,4 & $-348,7$ & 0 \\
11 & 2 & 593 & 287,2 & 1830 & 1780 & 1780 & $-451,4$ & 0 \\
12 & 2 & 1500,3 & 726,6 & 2385 & 1642,3 & 1642,3 & $-426,4$ & 0 \\
13 & 0 & 1126 & 545,3 & 0 & 0 & 0 & 0 & 0 \\
14 & 0 & 1650,6 & 799,4 & 0 & 0 & 0 & 0 & 0 \\
15 & 2 & 0 & 0 & 2084 & 190,45 & 1859,2 & $-581,2$ & 0 \\
16 & 0 & 2700 & 1307,7 & 0 & 0 & 0 & 0 & 0 \\
17 & 0 & 792 & 383,6 & 0 & 0 & 0 & 0 & 0 \\
18 & 0 & 522,2 & 253 & 0 & 0 & 0 & 0 & 0 \\
19 & 0 & 900 & 435,9 & 0 & 0 & 0 & 0 & 0 \\
20 & 0 & 638 & 309 & 0 & 0 & 0 & 0 & 0 \\
21 & 0 & 480,8 & 232,9 & 0 & 0 & 0 & 0 & 0 \\
22 & 2 & 0 & 0 & 810 & 184,69 & 557,77 & $-174,36$ & 0 \\
23 & 2 & 1800 & 871,8 & 2675 & 797,86 & 2162,2 & $-675,92$ & 0 \\
24 & 0 & 1050,3 & 508,7 & 0 & 0 & 0 & 0 & 148,34 \\
25 & 0 & 1071,4 & 518,9 & 0 & 0 & 0 & 0 & 178,93 \\
26 & 0 & 900 & 435,9 & 0 & 0 & 0 & 0 & 0 \\
27 & 2 & 704,7 & 341,3 & 4500 & 220,6 & 3046,4 & $-1465,2$ & 96 \\
28 & 2 & 0 & 0 & 1360 & 825,41 & 991,6 & -310 & 0 \\
29 & 0 & 900 & 435,9 & 0 & 0 & 0 & 0 & 0 \\
30 & 0 & 746,8 & 361,7 & 0 & 0 & 0 & 0 & 0 \\
31 & 0 & 900 & 435,9 & 0 & 0 & 0 & 0 & 0 \\
32 & 2 & 597 & 289,1 & 907,2 & 347,35 & 347,35 & -320 & 0 \\
33 & 2 & 0 & 0 & 1566 & 821,13 & 821,13 & $-337,09$ & 0 \\
34 & 0 & 477 & 231 & 0 & 0 & 0 & 0 & 0 \\
\hline \hline & & & & & & & &
\end{tabular}

\begin{tabular}{ccccccccc}
\hline \hline 35 & 0 & 653,6 & 316,6 & 0 & 0 & 0 & 0 & 0 \\
36 & 0 & 450 & 218 & 0 & 0 & 0 & 0 & 0 \\
37 & 2 & 0 & 0 & 1854 & 133,6 & 1276,7 & $-321,6$ & 0 \\
38 & 2 & 0 & 0 & 1710 & 55,29 & 1177,5 & $-368,08$ & 0 \\
39 & 2 & 0 & 0 & 2364 & 8,21 & 1642,3 & $-513,38$ & 0 \\
40 & 0 & 900 & 435,9 & 0 & 0 & 0 & 0 & 0 \\
41 & 2 & 450 & 218 & 3600 & 69,11 & 2875,6 & $-511,4$ & 0 \\
42 & 0 & 784,3 & 379,9 & 0 & 0 & 0 & 0 & 0 \\
43 & 0 & 900 & 435,9 & 0 & 0 & 0 & 0 & 0 \\
44 & 0 & 642,4 & 311,1 & 0 & 0 & 0 & 0 & 0 \\
45 & 0 & 1045 & 506,1 & 0 & 0 & 0 & 0 & 0 \\
46 & 2 & 619,8 & 300,2 & 1076,4 & 845,6 & 845,6 & $-166,7$ & 0 \\
47 & 0 & 1350 & 653,8 & 0 & 0 & 0 & 0 & 0 \\
48 & 2 & 1260 & 610,2 & 2736 & 1523,8 & 1884,2 & $-432,8$ & 0 \\
49 & 0 & 900 & 435,9 & 0 & 0 & 0 & 0 & 0 \\
50 & 0 & 900 & 435,9 & 0 & 0 & 0 & 0 & 0 \\
\hline \hline
\end{tabular}

B. Metodologi Penelitian

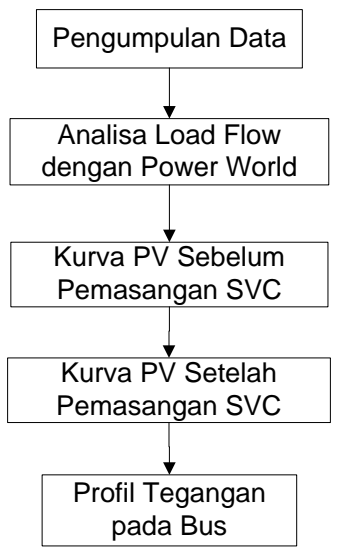

Gambar 3. Diagram alir algoritma genetika

Berdasarkan gambar 3 di atas maka metodologi simulasi yang digunakan dapat dijelaskan sebagai berikut:

1. Dengan menggunakan data-data yang dari sistem kelistrikan Jamali $500 \mathrm{kV}$. Data-data meliputi data pembangkitan, data beban, dan data saluran dari masingmasing bus. Kemudian dilakukan studi aliran daya (load flow analysis) dengan PowerWorld 18 simulator saat keadaan awal.

2. Analisa sistem jaringan untuk mengetahui perubahan tegangan menggunakan persamaan aliran daya.

3. Dari hasil running program didapatkan bus yang mengalami drop tegangan yang cukup tinggi, jika dilakukan penambahan beban $\mathrm{P}$ dan $\mathrm{Q}$.

4. Plot kurva PV pada saat sebelum pemasangan SVC pada bus sensitif.

5. Pemasangan SVC pada bus sensitif untuk perbaikan tegangan pada bus sensitif akan drop tegangan.

6. Plot kurva PV kembali untuk menunjukkan tegangan setelah pemasangan SVC pada bus sensitif. Profil tegangan pada bus drop tegangan akan terperbaiki, sehingga drop tegangan tidak terlalu besar. 


\section{SIMULASI DAN ANALISIS}

\section{A. Simulasi dan Analisis pada Sistem Jaringan}

Simulasi sistem tenaga listrik pada tugas akhir adalah menggunakan PowerWorld 18. Metode Newton Raphson digunakan untuk perhitungan aliran daya. Hasil running program load flow tegangan dapat dilihat pada tabel 3 . Tabel 3.

Hasil simulasi load flow tegangan

\begin{tabular}{|c|c|c|c|c|c|c|}
\hline \multirow{2}{*}{$\begin{array}{l}\text { No } \\
\text { Bus }\end{array}$} & \multirow{2}{*}{$\begin{array}{c}\mathrm{V} \\
(\mathrm{pu})\end{array}$} & \multirow{2}{*}{$\theta$} & \multicolumn{2}{|c|}{ Load } & \multicolumn{2}{|c|}{ Generator } \\
\hline & & & MW & MVAR & MW & MVAR \\
\hline 1 & 1 & 0 & 219 & 106,1 & 2071,95 & 1494,84 \\
\hline 2 & 0,99236 & $-0,75$ & 475,3 & 230,2 & 0 & 0 \\
\hline 3 & 1 & 0,47 & 0 & 0 & 1552,5 & $-176,9$ \\
\hline 4 & 1 & 0,43 & 0 & 0 & 1600 & 383,25 \\
\hline 5 & 0,98069 & $-2,87$ & 2185,2 & 1058,3 & 1197 & 1239,5 \\
\hline 6 & 0,9641 & $-4,27$ & 900 & 435,9 & 0 & 0 \\
\hline 7 & 0,96056 & $-4,51$ & 814 & 394,2 & 0 & 0 \\
\hline 8 & 0,96515 & $-4,72$ & 551 & 266,9 & 0 & 0 \\
\hline 9 & 0,96566 & $-4,8$ & 1950,3 & 944,6 & 0 & 0 \\
\hline 10 & 0,9875 & $-3,26$ & 900 & 435,9 & 1398 & 609,4 \\
\hline 11 & 0,99931 & $-2,58$ & 593 & 287,2 & 1830 & 1780 \\
\hline 12 & 0,98925 & $-2,63$ & 1500,3 & 726,6 & 2385 & 1642,3 \\
\hline 13 & 0,96656 & $-4,37$ & 1126 & 545,3 & 0 & 0 \\
\hline 14 & 0,95736 & $-5,15$ & 1650,6 & 799,4 & 0 & 0 \\
\hline 15 & 1 & 11,17 & 0 & 0 & 2084 & 190,45 \\
\hline 16 & 0,96 & $-3,96$ & 2700 & 1307,7 & 0 & 0 \\
\hline 17 & 0,95995 & $-4,26$ & 792 & 383,6 & 0 & 0 \\
\hline 18 & 0,96229 & $-4,09$ & 522,2 & 253 & 0 & 0 \\
\hline 19 & 0,9618 & $-4,52$ & 900 & 435,9 & 0 & 0 \\
\hline 20 & 0,98321 & $-0,28$ & 638 & 309 & 0 & 0 \\
\hline 21 & 0,9961 & 2,03 & 480,8 & 232,9 & 0 & 0 \\
\hline 22 & 1 & 2,73 & 0 & 0 & 810 & 184,69 \\
\hline 23 & 1 & 3,53 & 1800 & 871,8 & 2675 & 797,86 \\
\hline 24 & 0,96899 & $-0,11$ & 1050,3 & 508,7 & 0 & 0 \\
\hline 25 & 0,9629 & $-3,21$ & 1071,4 & 518,9 & 0 & 0 \\
\hline 26 & 0,97017 & $-0,91$ & 900 & 435,9 & 0 & 0 \\
\hline 27 & 1 & 4,1 & 704,7 & 341,3 & 4500 & 220,6 \\
\hline 28 & 1 & $-1,8$ & 0 & 0 & 1360 & 825,41 \\
\hline 29 & 0,97842 & $-2,32$ & 900 & 435,9 & 0 & 0 \\
\hline 30 & 0,97621 & $-1,51$ & 746,8 & 361,7 & 0 & 0 \\
\hline 31 & 0,97724 & -1 & 900 & 435,9 & 0 & 0 \\
\hline 32 & 0,98573 & $-0,38$ & 597 & 289,1 & 907,2 & 347,35 \\
\hline 33 & 0,9892 & $-0,22$ & 0 & 0 & 1566 & 821,13 \\
\hline 34 & 0,98413 & $-0,08$ & 477 & 231 & 0 & 0 \\
\hline 35 & 0,98281 & 0,74 & 653,6 & 316,6 & 0 & 0 \\
\hline 36 & 0,99261 & 3,27 & 450 & 218 & 0 & 0 \\
\hline 37 & 1 & 5,66 & 0 & 0 & 1854 & 133,6 \\
\hline 38 & 1 & 8,62 & 0 & 0 & 1710 & 55,29 \\
\hline 39 & 1 & 6,77 & 0 & 0 & 2364 & 8,21 \\
\hline 40 & 0,99515 & 6,42 & 900 & 435,9 & 0 & 0 \\
\hline 41 & 1 & 13,95 & 450 & 218 & 3600 & 69,11 \\
\hline 42 & 0,98129 & 4,12 & 784,3 & 379,9 & 0 & 0 \\
\hline 43 & 0,968 & 0,4 & 900 & 435,9 & 0 & 0 \\
\hline 44 & 0,98706 & $-0,79$ & 642,4 & 311,1 & 0 & 0 \\
\hline 45 & 0,99265 & $-0,92$ & 1045 & 506,1 & 0 & 0 \\
\hline 46 & 0,99712 & 0,31 & 619,8 & 300,2 & 1076,4 & 845,6 \\
\hline
\end{tabular}

\begin{tabular}{lcccccc}
\hline \hline 47 & 0,92808 & $-6,93$ & 1350 & 653,8 & 0 & 0 \\
48 & 1 & $-0,52$ & 1260 & 610,2 & 2736 & 1523,83 \\
49 & 0,99619 & $-0,88$ & 900 & 435,9 & 0 & 0 \\
50 & 0,95218 & $-9,91$ & 900 & 435,9 & 0 & 0 \\
\hline \hline
\end{tabular}

Dari hasil perhitungan aliran daya pada tabel 3 dapat dilihat bus yang memiliki tegangan abnormal yaitu bus yang memiliki tegangan dibawah $0,95 \mathrm{pu}(<95 \%)$. Dimana bus tersebut adalah bus 47 dengan tegeangan 0,92808 pu.

\section{B. Analisis Sensitifitas Tegangan}

Metode Newton Raphson digunakan untuk menganalisa sensitifitas tegangan pada masing-masing bus pada jaringan $500 \mathrm{kV}$ Jamali. Untuk mengetahui besar selisih tegangan $(\Delta \mathrm{V})$ pada masing-masing bus maka dilakukan iterasi sebanyak 100 kali pada bus berbeda sehingga dapat dilihat perubahan tegangan pada bus. Hasil running perhitungan dengan PowerWorld dapat dilihat pada tabel 4.

Tabel 4.

\begin{tabular}{ccccc}
\multicolumn{5}{c}{ Hasil tegangan bus setelah iterasi ke-100 } \\
\hline \hline Bus No. & Vi1 $(\mathrm{pu})$ & $\mathrm{Vi100}(\mathrm{pu})$ & $\Delta \mathrm{V}(\mathrm{pu})$ & $\mathrm{V}(\mathrm{kV})$ \\
\hline 1 & 1 & 1 & 0 & 500 \\
2 & 0,99236 & 0,99007 & 0,00229 & 495,036 \\
3 & 1 & 1 & 0 & 500 \\
4 & 1 & 1 & 0 & 500 \\
5 & 0,98069 & 0,97451 & 0,00618 & 487,256 \\
6 & 0,9641 & 0,95533 & 0,00877 & 477,663 \\
7 & 0,96056 & 0,95133 & 0,00923 & 475,666 \\
8 & 0,96515 & 0,95661 & 0,00854 & 478,304 \\
9 & 0,96566 & 0,95723 & 0,00843 & 478,613 \\
10 & 0,9875 & 0,98087 & 0,00663 & 490,433 \\
11 & 0,99931 & 0,99351 & 0,0058 & 496,755 \\
12 & 0,98925 & 0,98336 & 0,00589 & 491,68 \\
13 & 0,96656 & 0,95851 & 0,00805 & 479,254 \\
14 & 0,95736 & 0,94844 & 0,00892 & 474,221 \\
15 & 1 & 1 & 0 & 500 \\
16 & 0,96 & 0,95006 & 0,00994 & 475,031 \\
17 & 0,95995 & 0,95043 & 0,00952 & 475,216 \\
18 & 0,96229 & 0,95336 & 0,00893 & 476,679 \\
19 & 0,9618 & 0,95314 & 0,00866 & 476,568 \\
20 & 0,98321 & 0,97902 & 0,00419 & 489,512 \\
21 & 0,9961 & 0,99547 & 0,00063 & 497,733 \\
22 & 1 & 1 & 0 & 500 \\
23 & 1 & 1 & 0 & 500 \\
24 & 0,96899 & 0,95436 & 0,01463 & 477,179 \\
25 & 0,9629 & 0,94996 & 0,01294 & 474,98 \\
26 & 0,97017 & 0,96277 & 0,0074 & 481,384 \\
27 & 1 & 1 & 0 & 500 \\
28 & 1 & 0,99622 & 0,00378 & 498,111 \\
29 & 0,97842 & 0,97271 & 0,00571 & 486,356 \\
30 & 0,97621 & 0,971 & 0,00521 & 485,5 \\
31 & 0,97724 & 0,9723 & 0,00494 & 486,151 \\
32 & 0,98573 & 0,98066 & 0,00507 & 490,328 \\
33 & 0,9892 & 0,98415 & 0,00505 & 492,074 \\
34 & 0,98413 & 0,97997 & 0,00416 & 489,986 \\
35 & 0,98281 & 0,9792 & 0,00361 & 489,6 \\
\hline \hline & & & &
\end{tabular}




\begin{tabular}{ccccc}
\hline \hline 36 & 0,99261 & 0,99036 & 0,00225 & 495,182 \\
37 & 1 & 1 & 0 & 500 \\
38 & 1 & 1 & 0 & 500 \\
39 & 1 & 1 & 0 & 500 \\
40 & 0,99515 & 0,9902 & 0,00495 & 495,102 \\
41 & 1 & 1 & 0 & 500 \\
42 & 0,98129 & 0,96887 & 0,01242 & 484,436 \\
43 & 0,968 & 0,95331 & 0,01469 & 476,654 \\
44 & 0,98706 & 0,97922 & 0,00784 & 489,612 \\
45 & 0,99265 & 0,98914 & 0,00351 & 494,569 \\
46 & 0,99712 & 0,99016 & 0,00696 & 495,081 \\
47 & 0,92808 & 0,91002 & 0,01806 & 455,009 \\
48 & 1 & 1 & 0 & 500 \\
49 & 0,99619 & 0,99598 & 0,00021 & 497,988 \\
50 & 0,95218 & 0,91027 & 0,04191 & 455,135 \\
\hline \hline
\end{tabular}

\section{Kurva PV}

Kurva PV diperoleh dengan melakukan penambahan beban secara kontinyu pada suatu bus hingga mencapai titik kritis dari bus tersebut. Kharakteristik kurva PV tegangan berbanding terbalik dengan perubahan beban, tegangan semakin turun akibat adanya penambahan beban. Gambar 4 menunjukkan hasil plot kurva PV pada bus under voltage saat kondisi normal yang akan dijadikan kandidat untuk diperbaiki yaitu pada bus $14,25,47$, dan 50 .

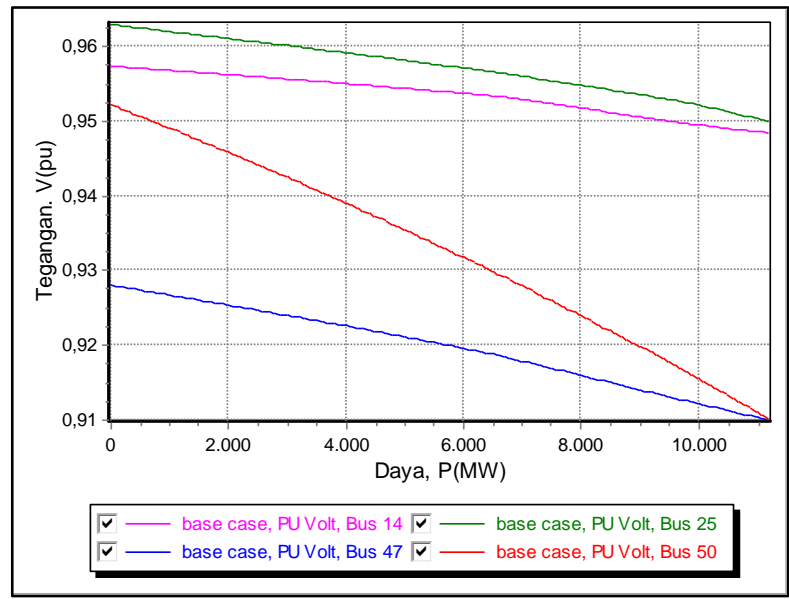

Gambar 4. Kurva PV bus 14, 25, 47, dan 50 kondisi normal

Perbaikan tegangan dilakukan dengan penambahan SVC dan dipilih pada bus yang memiliki sensitivitas tinggi. Hal tersebut dapat dilakukan dengan melihat sensitivitas dari masing-masing bus. Sensitivitas dari masing-masing bus dapat diketahui dengan melihat besar perubahan tegangan terhadap perubahan daya beban sistem. Setelah didapatkan kurva PV dari masing-masing bus maka ditentukan kurva PV untuk bus yang memiliki sensitifitas paling tinggi. Hasil plotting kurva PV pada bus yang memiliki sensitifitas paling tinggi dari semua bus dapat dilihat pada gambar 5 .

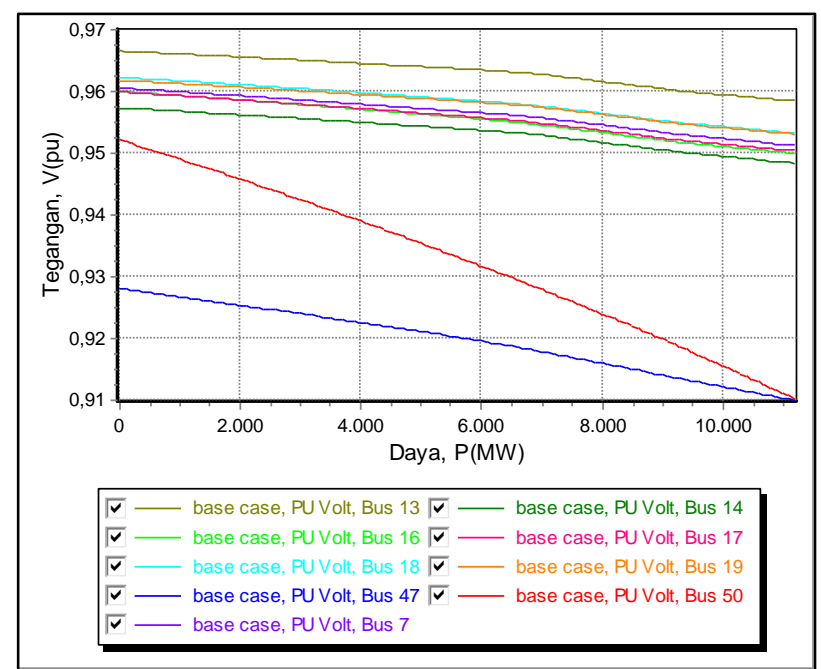

Gambar 5. Kurva PV bus sensitif

Pada percobaan dapat diketahui tingkat sensitivitas dari masing-masing bus. Dimana diambil sembilan bus dengan nilai sensitifitas paling tinggi. Berdasarkan kharakteristik kurva PV dapat diketahui bus yang memiliki sensitivitas paling tinggi ke paling rendah adalah bus 50,47, 16, 14, 17, 19, 7, 13, dan 18.

\section{Pemasangan SVC}

Untuk perbaikan tegangan pada bus yang mengalami under voltage, penempatan SVC diimplementasikan berdasarkan hasil dari kharakteristik kurva PV dari bus sensitif dan dipilih pada bus yang paling sensitif. Maka pemilihan bus yang akan dipasang SVC dipilih dari 3 bus paling sensitif yaitu pada bus 50, 47, dan 14.

Ukuran SVC yang dipasang pada masing-masing bus diasumsikan maksimal adalah 300 Mvar. Setelah simulai dijalankan maka besar daya reaktif yang diinjeksikan pada masing-masing bus adalah:
a. Bus $50=175,97$ MVar
b. Bus $47=288,45$ MVar
c. Bus $14=290,65$ Mvar

\section{E. Analisis Stabilitas Tegangan Setelah Penambahan SVC}

Dari hasil percobaan menunjukkan bahwa aliran daya setelah pemasangan SVC dapat memperbaiki jatuh tegangan pada bus yang sebelumnya mengalami under voltage. Gambar 6 menujukkan profil tegangan saat kondisi normal dan perubahan tegangan setelah pemasangan SVC. 


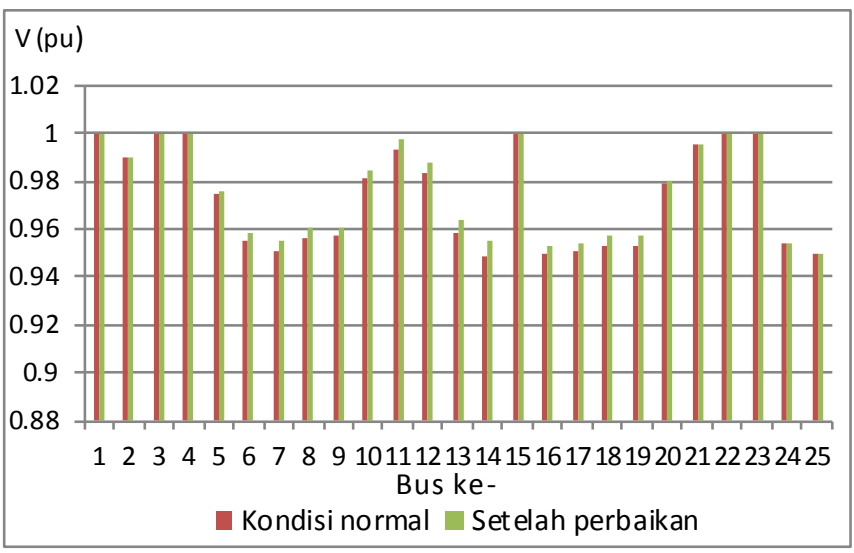

(a)

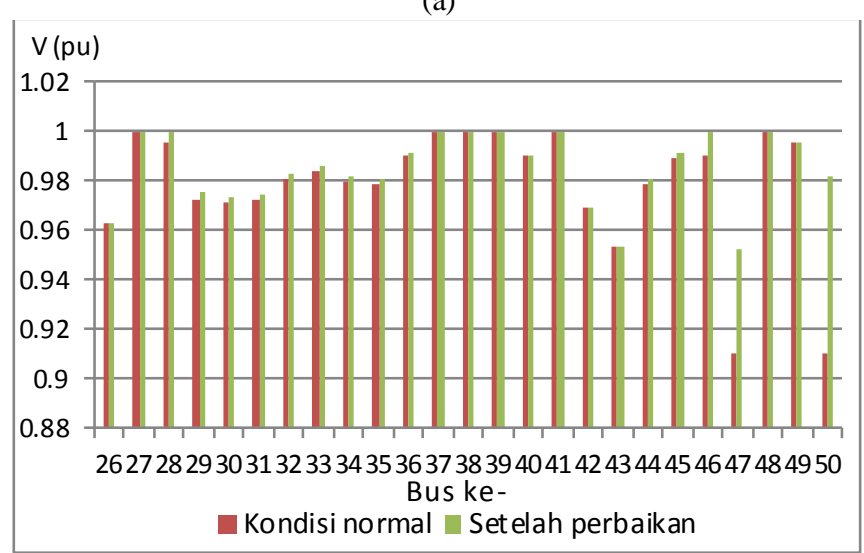

(b)

Gambar 6. Grafik profil tegangan bus sistem sebelum dan setelah perbaikan (a) bus no. 1-25, (b) bus no. 26-50

Akibat adanya penambahan SVC selain perbaikan profil tegangan juga dapat mengurangi rugi-rugi daya pada saluran. Rugi-rugi daya aktif yang pada saluran dapat tereduksi sebesar $1,68 \%$, dimana rugi-rugi awal yang semula bernilai 377,06 MW berkurang menjadi 370,72 MW.

Berikut hasil plot kurva PV setelah perbaikan dari bus under voltage (bus 14, 25, 47, dan 50) setelah diinjeksikan daya reaktif dari SVC dapat dilihat pada gambar 7.

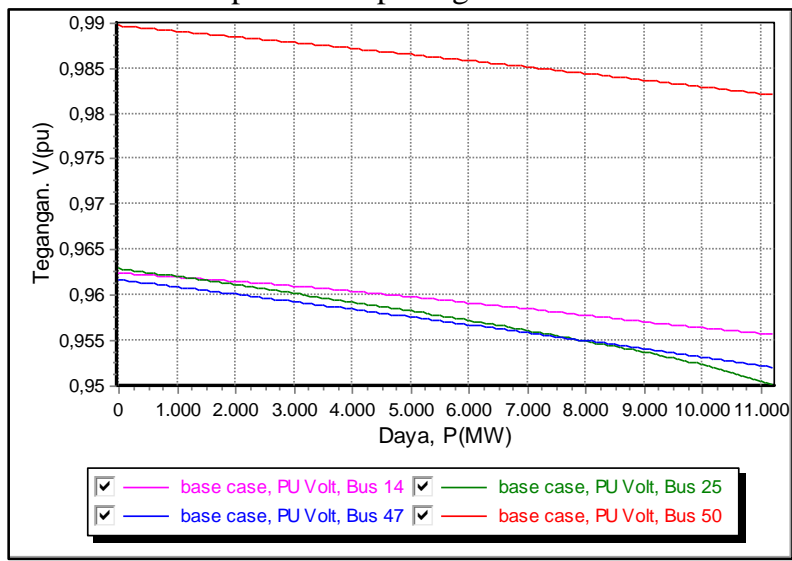

Gambar 7. Kurva PV bus 14, 25, 47, dan 50 setelah perbaikan
Gambar 7 merupkan grafik kurva PV dari bus-bus yang mengalami under voltage yang menunnjukan adanya perubahan tegangan setelah pemasangan SVC, dimana tegangan pada bus meningkat dan berada pada batas kestabilan tegangan. Untuk mengetahui kestabilan tegangannya, beban dinaikkan secara berkala dari kondisi normal hingga mencapai batas maksimum penambahan beban atau kondisi kritis pada tiap-tiap bus beban yaitu sebesar 11208 MW. Sehingga dapat dilihat setelah dilakukan pemasangan SVC titik kritis dari masing-masing bus meningkat. Dimana nilai kritis dari masing-masing bus yaitu: bus $14=0,95562$ pu, bus $25=$ 0,95010 pu, bus $47=0,95198$ pu, dan bus $50=0,98208$ pu

\section{KESIMPULAN}

Berdasarkan hasil yang didapatkan dari simulasi dan analisis pada tugas akhir ini, dapat diambil beberapa kesimpulan sebagai berikut:

1. Penambahan beban $\mathrm{P}$ dan $\mathrm{Q}$ terhadap sistem transmisi Jawa-Madura-Bali (Jamali) $500 \mathrm{kV}$ dapat mengakibatkan penurunan tegangan yang relatif besar.

2. Kurva PV digunakan untuk menentukan tingkat stabilitas dari masing-masing bus, sehingga dapat dilihat sensitivias dari masing-masing bus.

3. Perbaikan tegangan dengan pemasangan SVC pada bus sensitif memberikan hasil yang memuaskan dimana diperoleh tegangan sistem yang stabil.

4. Adanya pemasangan SVC dapat memperbaiki profil tegangan sehingga berada pada batas toleransi, adapun profil tegangan terendah sebelum pemasangan SVC berada pada bus 47 yaitu 0,91002 pu, sedangkan setelah perbaikan profil tegangan terendah berada pada bus 25 yaitu $0,9501 \mathrm{pu}$.

\section{DAFTAR PUSTAKA}

[1]. N. G. Hingorani and L. Gyugyi, "Understanding FACT S-concepts and technology of flexible AC transmission systems," IEEE press, First Indian Edition, 2001.

[2]. Khandani, S. Soleymani, B. Mozafari, "Optimal Placement of SVC To Improve Voltage Profile Using Hybrid Genetics Algorithm And Sequential Quadratic Programming", conference on electrical power distribution network (EPDC), 2011.

[3]. Anju Gupta, P.R. Sharma, "Optimal Placement of FACT S Devices for Voltage Stability Using Line Indicator", IEEE, 2012.

[4]. M. Karami, N. Mariun, "Determining optimal location of Static Var Compensator by means of genetic algorithm" IEEE, 2011. 